\title{
Family dynamics in face of Alzheimer's in one of its members*
}

\author{
A dinâmica familiar diante da doença de Alzheimer em um de seus membros \\ La dinámica familiar ante la enfermedad de Alzheimer en uno de sus miembros
}

Barbara Alana Vizzachi ${ }^{1}$, Celina Daspett ${ }^{1}$, Maria Goreti da Silva Cruz ${ }^{1}$, Ana Lúcia de Moraes Horta ${ }^{1}$

\begin{abstract}
* Extracted from the report submitted to the Programa Institucional de Bolsas de Iniciação Científica (PIBIC) "A dinâmica familiar frente à doença de Alzheimer em um de seus membros", Universidade Federal de São Paulo, 2014.

${ }^{1}$ Universidade Federal de São Paulo, Escola Paulista de Enfermagem, São Paulo, SP, Brazil.
\end{abstract}

\begin{abstract}
Objective: To understand the family dynamics when there is a member in the residence with Alzheimer's disease. Method: A study of qualitative approach, using the creative sensitive method (CSM), and with participation of two families who had a member with Alzheimer's disease at home. Results: Three categories emerged: Effects of Alzheimer's disease and the family dynamics; Development process of Alzheimer's disease and Coping strategies in face of the disease. Conclusion: It was possible to know the manifestations and consequences of Alzheimer's disease in the family, such as mutual help, the mobilization of resources to activate memories of the past, spirituality and faith. There was also understanding of the structure of family dynamics.
\end{abstract}

\section{DESCRIPTORS}

Alzheimer Disease; Dementia; Family; Family Nursing; Geriatric Nursing. 


\section{INTRODUCTION}

Population aging is a global process related to factors such as increased life expectancy, advances in medicine and improved quality of life, resulting in a progressive growth of chronic degenerative diseases, including dementia. Alzheimer's disease $(\mathrm{AD})$ is the most frequent cause of dementia in the world, affecting directly the family life, particularly by increasing the burden of care ${ }^{(1)}$.

According to estimates of a study in Portugal, the expectation in relation to the growth of the elderly population worldwide is related to the growth of dementia. It concluded that $64 \%$ of people in the age group of over 80 years develop dementia, alerting for the importance of recognizing the disease and defining treatment and support strategies ${ }^{(2)}$.

$\mathrm{AD}$ is a neurological disease characterized by progressive dementia with initial impairment of the memory for recent events. Subsequently, there is deterioration of $\operatorname{cog}-$ nitive functions such as constructive apraxia, agnosia and aphasic disorders. It has a clinical picture of slow, variable and irreversible evolution, moving towards a vegetative state within 10 to 15 years from the onset of symptoms ${ }^{(3)}$.

The symptoms of $\mathrm{AD}$ can be described in three stages, namely: the initial, intermediate and terminal phases. The initial phase lasts on average 2-4 years and is characterized by language difficulties, significant loss of recent memory, time and space disorientation, signs of depression, aggressiveness and loss of interest in activities. The intermediate phase ranges from 2-10 years, with increasing loss of memory and beginning of changes in the language, reasoning, and motor disabilities. The terminal phase is characterized by bed confinement, silence, intestinal or urinary retention, and adoption of the fetal position due to contractures. These progressive, cognitive and behavioral symptoms influence the probability of performing the Activities of Daily Living, making patients increasingly dependent on their families ${ }^{(3)}$.

Regarding the care of the person with $\mathrm{AD}$, the current trend is to recommend that the elderly remain in their homes under the care of their families, aiming for their comfort and dignity. This situation implies that some family members are held responsible for the care of these elderly without having received any specific training or preparation, with subsequent physical, psychological, social and financial burden.

The emotional relationships of the family are constantly changing as a result of unexpected factors like the onset of a chronic degenerative disease such as AD. The way a family evaluates and manages the care depends on the availability of support networks, coping strategies, characteristics of each individual and family, and the meaning of caring for those involved in the process. The family involvement in the care is directly related to their perception of the benefits promoted by the interventions for both the person with $\mathrm{AD}$ and their family members. Therefore, it is important to explore emotional and relational aspects, personality factors and the relationship among members before the disease ${ }^{(4-5)}$.

Therefore, it is increasingly necessary that the family understands how is living with a member who is physically present, but psychologically absent, and also knows about the changes in the family routine, including the psychological and social aspects of those involved. Thus, nursing professionals must work together with families, playing their role in diagnosing and planning the needs of the client/ family, which are extremely important in the care and support to the patient, considering that family dynamics may suffer changes.

Given the above, this study was aimed at understanding the family dynamics when there is an Alzheimer's patient at home, in order to contribute with families and the nursing team in the development of disease coping strategies.

\section{METHOD}

This is qualitative study, developed through the adapted creative sensitive method (CSM), considering the specific experiences of families and the difficulties found when gathering the largest number of family members at the time of data collection. The basic principle of the CSM is the combination of group discussions with artistic productions, providing a favorable space to (re)build strategies for strengthening the health care of these people and creating a dialogical-dialectical relationship among participants based on the reference of Paulo Freire, characterized by the appreciation of the uniqueness of each group member ${ }^{(6)}$.

The study participants were randomly selected, inviting the families with an $\mathrm{AD}$ patient at home. The contact was made from the list of patients registered in the group of the Service Center and Nursing Education (CAENF - Centro de Assistência e Educação em Enfermagem), but people with $\mathrm{AD}$ did not participate in the research.

The study was examined and approved by the CEP/ UNIFESP under No. 203.104, respecting the ethical and legal principles followed in investigations involving human subjects, as required by Resolution No. 466 of December 12, 2012 of the National Health Council.

Two families participated in the study. Data collection was held in the households during the year 2014 and conducted in three stages. In the first stage, the genogram was designed together with the family members who were present and with the primary purpose of mapping the existing relationships $s^{(7)}$. Then, the semi-structured interview was conducted and recorded by using the following guiding question: For you, how is life in family having a member with Alzheimer's disease?

In the second stage, the CSM was adapted to carry out a constructive artistic production that consisted of a collage of words and figures, indicating the $\mathrm{AD}$ process in the family timeline. This activity was followed by a moment of reflection on the changes in the family dynamics and the feelings and difficulties involved. The third stage of the study consisted in exploring the coping strategies.

For the analysis, interviews were transcribed verbatim, outlined, analyzed and discussed. From the data saturation emerged categories, without the need to return to participants, but with the commitment of presenting the results to the families. To preserve the identities of the families, we used their relationship with the patient with $\mathrm{AD}$ for identification. 


\section{RESULTS}

The analysis of the transcribed interviews resulted in three categories: Effects of Alzheimer's disease and the family dynamics; Development process of Alzheimer's disease and Coping strategies in face of the disease.

\section{Effects of Alzheimer's Disease AND the familiy DYNAMICS}

Family members reported that, by the need of care, they could reflect on the education, patience and love they had received from the ill relative throughout their growth. The only way they saw as a form of retribution was the care for the family member with Alzheimer's disease with the same love. As a result, there was the sense of role reversal, with the daughter assuming the role of caregiver.

It looks like I'm taking care of a child, it seems that she has decharacterized herself, my mother is infantilized. And we tell her off as if it were a child, the same way you talk to your child. I tell her: Mom, you've got a bad-smelling sweat, it was $40^{\circ}$ today, you gotta take a shower, it's hot (Mandacaru, Family 2).

In the reports, the family members who introduced themselves as the primary caregivers, regardless if imposed or not, stated they felt overwhelmed because of the complexity of care and the great emotional burden involved in caring for a person for whom they had affection.

I say: Dad, she's sick, you know she's not like that, never behaved that way, she's ill, so she forgets, leaves things behind, we gotta be patient. Then he says: 'Oh, child, but this cross is too heavy for me (...)'. Sometimes I think it's heavy, too. But I'm so used to it, we gotta get used to it, there's no other way (Sansão do Campo, Family 2).

The family member was exposed to the risk of the Alzheimer's patient experiencing a fall, infection or pressure ulcers, not necessarily due to the omission or negligence of care, but because of the own clinical conditions of the patient. However, this did not put an end to the guilt felt by the family member because, according to reports, they carried with themselves the feelings of remorse and helplessness in face of the disease and its inferences. They felt responsible for not being able to make the patient's suffering decrease, exacerbating this feeling when they believed they had increased the patient's pain.

The day my Mom had a seizure in the ICU, I almost made the doctor even more concerned. I made a scene ... I thought the situation was my fault. I thought I hadn't provided proper care, that I hadn't protected her enough (Avenca, Family 1).

She (Rosa - sister) was changing my Mom's diaper, but did not realize and twisted her leg, and as it is more sensitive, she ended up breaking the femur. I wouldn't stop crying and kept saying that our mother couldn't go through one more thing, 'cause she already has the disease, she's already with dementia (Girassol, Family 1 ).

With disease progression, the families considered hiring a caregiver to help them, to take over the routine care, or even taking the patient to a nursing home because of the difficulty with coordinating the care demands of the patient with work. However, the nursing home option was not always well seen by the family members themselves, because this act was considered abandonment.

We've already thought about hiring a caregiver, but she (Palmeira Imperial) didn't accept it. Our biggest problem is the medicine because it is not only giving the medication at the right times, we have to convince her to take it, stay by her side, monitor... And my Dad has no patience for it (Mandacaru, Family 2).

She always took care of us with no babysitter, no daycare, why can't we care for her? She was only one and we are five! (Girassol, Family 1).

\section{DeVelopment Process of Alzheimer's disease}

With the diagnosis of $\mathrm{AD}$, different feelings and thoughts emerged in the families. They had to face the sadness of the diagnosis and accept the disease severity. With evolution of a poor prognosis, the family member with $\mathrm{AD}$ became increasingly dependent.

In the statements, the ambivalence of acceptance versus denial of the disease became evident, as well as the questioning and the view that the disease is a punishment. When the family witnessed and experienced the establishment of the disease, it was possible to seek the understanding of the disease and adapt to its care.

We've lived the first months of the disease, the discovery, with difficulty, then came the acceptance ... But some accept the disease faster and others take a little longer, so we used to quarrel more during that time (Girassol, Family 1).

I think he (Father) doesn't understand what Alzheimer's disease actually is, I guess that's the big problem. Making an analogy, it's the same with depression ... Those who don't know it, don't live with it, don't know, they think depression is fussiness. And that's how he sees it (Sansão do Campo, Family 2).

According to the families' reports, the most difficult period experienced during the $\mathrm{AD}$ process was related to the patient being bedridden, showing the severity of the disease and no longer allowing the participation of the sick patient in the family moments, not even physically.

The hardest for me is now that she is bedridden...

Because when she was in a wheelchair in the liv-

ing room watching $T V$ with us, it was a little better, but after she had this ulcer and can only 
be lying down, it's worse. We can't wait for her to be sitting in the living room watching $T V$ with us, then it'll be more comforting (Girassol, Family 1).

With the evolution of the disease, appear the fears about the future and the anguish of being forgotten.

My greatest fear is the time when she looks at me and doesn't recognize me (Mandacaru, Family 2).

In the terminal phase of AD, patients lose the ability to speak, recognize their loved ones and express their feelings. The family members felt happy and rewarded for all the effort when the patients could demonstrate their feelings, whether through gestures or words, and remembered the past as a good memory and missed the time when the person was participating.

It is rare, but when she gives a smile it is the most beautiful thing (Avenca, Family 1).

I used to get home and she'd tell me about all the soap operas, I don't know how could she watch them all ... and I never did, I didn't understand anything she was talking about, but I listened. Now, she no longer interacts with anything or anyone (Sansão do Campo, Family 2).

Because of the AD, the family started to live in constant interaction with the health team. In the reports, the family members emphasized the importance of the nurses' guidance on the care of the patient with Alzheimer's disease. By contrast, they declared a lack of confidence in the hospital health staff due to the appearance of pressure ulcers in their sick relative.

The lecture was very good for us, the nurse was great (...)' cause we learned, she said we cannot argue nor fight (Girassol, Family 1).

The appearance of this bed sore was carelessness at the Hospital... Because it happened there, whereas I took care of my Mom for ten years and she never had such a thing (Rosa, Family 1).

\section{COPING STRATEGIES IN FACE OF THE DISEASE}

The family system was affected throughout the whole process of $\mathrm{AD}$, with possible disorganization. The changes affected the family members in varying degrees of intensity. The relatives have reported the importance of family union and hope to face this condition.

We gotta have hope. Of eventually finding a cure, no matter if not on time to help my mother, but to help other people so they don't have to go through this (Avenca, Family 1).

The belief in God during the process of AD was identified in the speeches of the participating families. In reports of the moments of crisis, such as the discovery of the disease, they stated to seek comfort and help in God. Thoughts about the time of death of the patient are also entrusted in God. The belief was present for the study participants, and
God was seen as someone close, who could assist the family in coping with the difficult times of AD.

We cling to God, because only God can help us, give us strength to deal with this (Avenca, Family 1).

I ask God to give her a peaceful death, that she doesn't suffer, just goes to sleep and doesn't wake up any more ... I don't want her to go to the hospital, she has already suffered a lot (Rosa, Family 1).

\section{DISCUSSION}

The results of this study showed that the family's experience with a member affected by $\mathrm{AD}$ requires a reorganization of the family structure and dynamics, involving feelings and emotions. The interactions between family members, behavior and attitude toward the events related to $\mathrm{AD}$ are influenced by the transgenerational values rescued from the members. These processes are transmitted by the family and remain present throughout the family history and generations, and consequently the family members give distinct importance to values, beliefs, myths and secrets.

The diagnosis of AD is a threat to the stability and homeostasis of the family, because it brings successive losses of independence, generating fears and consequently, sensations common to the grieving process such as feelings of anxiety, sadness and irritation ${ }^{(8)}$. The family members mentioned sadness due to the diagnosis, fear because of the uncertainty of the future and lack of knowledge, and difficulty of accepting the disease.

The family of the person with Alzheimer goes through several phases, from diagnosis to the advanced stage of the disease, with feelings of denial and acceptance in face of the excessive involvement ${ }^{(3,8)}$. Usually, for the family is difficult to have dimension of the changes that will occur in their daily lives, especially when they do not have much knowledge about the disease, the care to be performed and the care management. It is necessary to support adequately the sick patient in face of the suffering, fear and anxiety. These factors decrease as the family acquires knowledge about the disease and its evolution. The search for information about the medical diagnosis and its explanations are not enough to suppress the feelings experienced in AD. In this respect, the role of the multidisciplinary team can help families with understanding the process.

Family members reported anger, indignation and the view of the disease as a punishment or trial. These feelings originated in response to the premature and abrupt termination of the existential activities and constructions that will be unfinished. Over time, arise awareness and acceptance of the disease, and families recover their balance to manage anxiety and distress ${ }^{(9)}$.

The family caregiver role, assumed here by daughters who returned the care received, has emotional and financial burden. Most caregivers are not formally employed because caring for the sick patient fully occupies their daily schedule. Moreover, the other family members may lack in 
interest for care, aggravating the physical and psychological burden of the primary caregiver. This situation may lead to clinical pictures of depression, anxiety, fear, frustration, stress and consequently the use of various drugs, particularly psychotropic ${ }^{(10)}$.

The burden and the difficulty of accepting the disease can take on characteristics of the anticipatory grieving process experienced by the family, starting in the diagnostic stage of $\mathrm{AD}$ and in the losses of concrete aspects such as health, memory and removal from the usual routine, along with subjective aspects, such as the loss of autonomy, the anxiety and anguish $^{(11)}$.

The processes of construction, (de)construction and (re) construction are experienced daily by the families, leading them to recognize themselves, readapt and adjust to a new reality. An example of this is the role reversal in the parent/child relationship, which was described by relatives as bringing much suffering and difficulty of acceptance and coexistence. While caregivers, the role reversal in dementia requires review and emotional and psychological surveillance from children or younger people, because this situation changes the structure elaborated by the development of relations established throughout life ${ }^{(4)}$.

According to a study, with the disease evolution, the primary caregivers assume greater responsibility and begin to dedicate themselves almost entirely to the person with $\mathrm{AD}^{(8)}$. For the study participants, those who were once seen as pillars of the family, become increasingly dependent on the family members to carry out the activities of everyday life ${ }^{(5)}$. In this sense, the primary caregiver feels more burdened than the secondary caregivers ${ }^{(8)}$. In this scenario, nursing has the mission to assist and treat the patient and include the family in comprehensive care, promoting dialogues and care strategies as the $\mathrm{AD}$ progresses, to make the family feel more comforted, guided and heard in relation to their worries and fears.

It is necessary to awaken the attention of health professionals to broaden their look at the context of people involved in the process of AD. To this end, it is expected that health education activities are developed, in addition to integrated patient care, conducting groups of self-help and/or mutual help, home visits, nursing appointments and, from this, actions and interventions are developed ${ }^{(9)}$. A way to approximate these families and the health team is through a strategy proposal defined to offer a more resolute and humane care.

Some participants reported the appearance of pressure ulcers during hospitalization, a fact attributed to the lack of intervention and neglect of professionals. This worsening was reported by relatives as a process marked by pain, discomfort and suffering. It also caused the emergence of a sense of guilt on the family member, as well as remorse and the feeling of helplessness for not being able to prevent the episode or reduce the patient's suffering ${ }^{(10)}$.

The perception of the physical presence of the family member with $\mathrm{AD}$, but his/her psychological or emotional absence leads the person to not present the characteristics that once made him/her recognize him/herself as the one he/she used to be - the same happening with the role and function in the family ${ }^{(9)}$. The ambiguity experienced by family is permeated with conflicting feelings and observed in the speeches of families, because at the same time they fear thinking and/or talking about the death of the family member, they wish this situation comes to an end.

The most common psychological response in face of death is fear, a universal feeling that affects everyone, regardless of age, socioeconomic status, gender and religion, and presents itself with many facets. A person thinking about the death of another can relate it to the difficulty of seeing the suffering and the disintegration of the other, and to feelings of helplessness, fear of what comes after death, of judgment, divine punishment, rejection and the loss of the relationship. There is also the fear of extinction and the threat of the unknown ${ }^{(12)}$. Among the strategies used by families to reduce the suffering, is the mutual help with basic chores of the patient's daily life for promoting and maintaining care in the initial phase. There is also the mobilization of resources for remembrance of the past, awakening their memories and giving them strength to live with the disease.

Spirituality and faith were facilitators in the development process of the disease, associated with hope and the belief of a higher/divine existence that gives strength and feeds the desire of improvement and cure every day. In some families, the religion while health care practice is part of the cultural background and has significant meaning in the care process - especially in the case of chronic disease conditions ${ }^{(13)}$. Religiosity and spirituality act as mediators in the perception of burden or benefits arising from the task of caring, softening the negative impact of AD. The spiritual lessons learned give faith for experiencing the future moments with more tranquility and serenity, by enabling a better acceptance of reality and providing answers to what cannot be explained by humans. For this reason, many individuals usually seek support in religion and the sacred, which begin to occupy an important place in their lives, helping them to find answers to the necessary confrontations ${ }^{(13)}$.

\section{CONCLUSION}

We believe the objectives of this study were achieved because it was possible to know the manifestations and consequences of Alzheimer's disease in the family, identify coping strategies and understand how the family dynamics is structured, revealed in feelings and different ways to identify the changes brought to the family by the disease.

Among the limitations of this study, we highlight the difficulty to include more family members in interviews and apply the creative sensitive method. These instruments were selected for facilitating the narratives of participants in relation to Alzheimer's disease, since the information obtained could be applied to other family contexts. Thus, this study reflected the need to include caregivers and the family as people who also need care. 


\section{RESUMO}

Objetivo: Compreender a dinâmica familiar quando há um membro com Alzheimer em domicílio. Método: Estudo com abordagem qualitativa, Método Criativo-Sensível (MCS), do qual participaram duas famílias que possuíam em domicílio um membro com Alzheimer. Resultados: Tiveram origem três categorias: Repercussões da doença de Alzheimer e a dinâmica familiar; Processo de desenvolvimento da doença de Alzheimer e Estratégias de enfrentamento diante da doença. Conclusão: Foi possível conhecer as manifestações e repercussões da doença de Alzheimer na família, como ajuda mútua, mobilização de recursos para ativar as lembranças do passado, espiritualidade e fé. Houve também entendimento da estrutura da dinâmica familiar.

\section{DESCRITORES}

Doença de Alzheimer; Demência; Família; Enfermagem Familiar; Enfermagem Geriátrica.

\section{RESUMEN}

Objetivo: Comprender la dinámica familiar cuando hay un miembro con Alzheimer en domicilio. Método: Estudio con abordaje cualitativo, Método Creativo Sensible (MSC), del que participaron dos familias que tenían en domicilio un miembro con Alzheimer. Resultados: Tuvieron origen tres categorías: Repercusiones de la enfermedad de Alzheimer y la dinámica familiar; Proceso de desarrollo de la enfermedad de Alzheimer; y Estrategias de enfrentamiento a la enfermedad. Conclusión: Fue posible conocer las manifestaciones y repercusiones de la enfermedad de Alzheimer en la familia, como ayuda mutua, movilización de recursos para poner en marcha los recuerdos del pasado, espiritualidad y fe. Hubo también entendimiento de la estructura de la dinámica familiar.

\section{DESCRIPTORES}

Enfermedad de Alzheimer; Demencia; Familia; Enfermería de la Familia; Enfermería Geriátrica.

\section{REFERENCES}

1. Abdollahpour I, Noroozian M, Nedjat S, Majdzadeh R Caregiver burden and its determinants among the family members of patients with dementia in Iran. Int J Prev Med. 2012;3(8):544-51.

2. Santana I, Farinha F, Freitas S, Rodrigues V, Carvalho A. The epidemiology of dementia and Alzheimer disease in Portugal estimations of prevalence and treatment-costs. Acta Med Port. 2015;28(2):182-8.

3. Wajman JR, Schultz RR, Marin SMC, Bertolucci PHF. Correlation and adaptation among functional and cognitive instruments for staging and monitoring Alzheimer's disease in advanced stages. Rev Psiquiatr Clín. 2014;41(1):5-8.

4. Kaitlyn PR, Neena LC. Meaningful activity for persons with dementia: family caregiver perspectives. AM J Alzheimer Dis Other Demen. 2015;30:559-68.

5. Schiffczyk C, Romero B, Jonas C, Lahmeyer C, Müller F, Riepe MW. Appraising the need for care in Alzheimer's disease. BMC Psychiatry. $2013 ; 13: 73$

6. Soratto J, Pires DEP, Cabral IE, Lazzari DD, Witt RR, Souza SCA. A maneira criativa e sensível de pesquisar. Rev Bras Enferm. 2014;67(6):994-9.

7. Wright LM, Leahey M. Enfermeira e famílias: um guia para avaliação e intervenção na família. 4ª ed. São Paulo: Roca; 2009.

8. Borghi AC, Castro VC, Marcon SS, Carreira L. Sobrecarga de familiares cuidadores de idosos com doença de Alzheimer: um estudo comparativo. Rev Latino Am Enfermagem. 2013;21(4):876-83.

9. Oliveira APP, Caldana RHL. As repercussões do cuidado na vida do cuidador familiar do idoso com demência de Alzheimer. Saude Soc. $201 ; 21(3): 675-85$

10. Palmer JL. Preserving personhood of individuals with advanced dementia: lessons from family caregivers. Geriatr Nurs. 2013;34(3):224-9.

11. Cardoso EAO, Santos MA. Luto antecipatório em pacientes com indicação para o transplante de células-tronco hematopoéticas. Ciênc Saúde Coletiva. 2013;18(9):2567-75.

12. Menezes TMD, Lopes RLM. Significados do vivido pela pessoa idosa longeva no processo de morte/morrer e luto. Ciênc Saúde Coletiva. 2014;19(8):3309-16.

13. Koenig HG. Religion, spirituality, and health: the research and clinical implications. ISRN Psychiatry. 2012;2012:278730. 